О. В. Панова

Київський національний університет будівництва і архітектури, Київ, Україна

\title{
ДОСЛДЖЕННЯ ЗАХИСНИХ ВЛАСТИВОСТЕЙ МЕТАЛЕВИХ ЕЛЕКТРОМАГНІТНИХ ЕКРАНІВ ТА ВИЗНАЧЕННЯ УМОВ ЇХ МАКСИМАЛЬНОЇ ЕФЕКТИВНОСТІ
}

\begin{abstract}
Анотація. На основі аналізу даних про екранування електромагнітних полів наднизьких та ультрависоких частот будівельними та облицювальними матеріалами зроблено висновки, що найбільш доцільним з технічних та економічних міркувань $є$ облицювання захисними матеріалами внутрішніх поверхонь будівель. Наведено коефіцієнти екранування розробленими металополімерними матеріалами електромагнітних полів різних частот. Для електромагнітних полів частотами 2,4-2,6 ГГц коефіцієнти екранування складають 2,44 (за товщини екрана 5 мм) та 3-52 (за товщини екрана 10 мм). Коефіцієнти відбиття складають 0,06-0,32. Зміна концентрації феромагнітної субстанції становить 5-20\% (за вагою). За таких умов зниження напруженості магнітного поля промислової частоти складають 1,2-15,0 (за товщини екрана 5 мм) та 2,3-38,0 (за товщини екрана 10 мм). Наведено порядок оцінювання ефективності екранування високочастотного екранованого поля тришаровою структурою, виходячи зі значення діелектричної проникності несучого матеріалу та мінімальної довжини електромагнітної хвилі діапазону екранованого поля. Для одночасного екранування магнітного поля промислової частоти провідний шар повинен бути феромагнітним. Для цього можна застосувати металополімер з великою концентрацією залізорудного концентрату.
\end{abstract}

Ключов і слов а: електромагнітні поля; екранування; коефіцієнти екранування; облицювальний захисний будівельний матеріал.

\section{Вступ}

Підвищення електромагнітного навантаження на довкілля, тобто збільшення кількості та потужності зовнішніх джерел полів та випромінювань впливає на електромагнітну обстановку усередині будівель і споруд.

Актуальною задачею $є$ захист від впливу техногенних полів на людей у виробничих та побутових умовах. Найбільш сучасний метод захисту екранування [1].

Відомо, що будівельні матеріали й конструкції частково екранують електромагнітні поля й випромінювання і для цього розробляються захисні матеріали, суміші або концентрати з керованими коефіцієнтами екранування у різних частотних діапазонах [2]. Але кількісні дані щодо коефіцієнтів екранування навіть традиційних і поширених будівельних матеріалів дуже різняться і потребують уточнення. У багатьох випадках потребує впровадження додатковий захист виробничих і побутових приміщень спеціальними екранувальними матеріалами. Враховуючи, що у цьому випадку необхідне облицювання великих площ, одним з головних критерій при розроблені захисних матеріалів $\epsilon$ їх вартість та технологічність при застосуванні, а також стійкість за довгострокової експлуатації.

У промислових будівлях, що потребують екранування, окремих приміщеннях необхідна наявність даних про екранувальні властивості облицювальних матеріалів та розроблення засобів підвищення таких властивостей. Ці дані необхідні не тільки для захисту персоналу на виробництві чи підприємстві, а й технічного захисту інформації та забезпечення електромагнітної сумісності чутливого коштовного електронного обладнання [3].

Тому усі ці заходи та ефективність засобів захисту повинні бути певним чином раціоналізовані.
Аналіз останніх досліджень і публікацій. Ознайомлення 3 довідковими даними щодо екранування електромагнітних полів будівельними матеріалами та конструкціями дозволяє дійти висновку, що вони не однозначні та у багатьох випадках викликають сумніви. Майже в усіх довідниках наведено, що цегляна стіна завтовшки 0,7 метрів знижує рівні електромагнітних випромінювань сантиметрового діапазону на 16,0-21,0 дБ. Шлакобетонні стіни - на 14,5-20,5 дБ. Монолітнобетонні будівлі - 6,016,0 дБ та 10,0-30,0 дБ у залежності від кроку арматури. За таких коефіцієнтів екранування (принаймні 10-100) сигнали базових станцій мобільного зв'язку, які працюють на довжинах хвиль сантиметрового діапазону (17,0-11,5 см) майже повністю повинні зникати (інтенсивність випромінювань станцій майже ніколи не перевищує $0,10-0,08$ мкВт/см²). Але цей факт суперечить повсякденній практиці: практично в усіх залізобетонних будівлях мобільний зв'язок функціонує стабільно.

Відсутність надійних систематизованих даних щодо захисних властивостей будівельних та облицювальних матеріалів певним чином обумовлене відсутністю таких вимог у чинних будівельних нормax [4]. Тому дослідження й практичні розробки у цьому напрямку поодинокі і не носять системний характер. Практично усі публікації щодо захисних властивостей будматеріалів стосуються електромагнітних випромінювань ультрависоких частот [5].

У роботі розглянуто ефективність екранування різними матеріалами високочастотних випромінювань. Але розглянуті матеріали дуже складні та мало придатні для застосування ззовні будівель і мають велику вартість.

Дослідження [6] присвячене визначенню змінам електромагнітної обстановки через відбиття електромагнітних хвиль базових станцій мобільного зв'язку від вертикальних та горизонтальних метале- 
вих облицювальних покриттів. Отримані дані свідчать, що розташування кількох випромінювачів у зоні прямої видимості за наявності відвальних поверхонь значно погіршує електромагнітну обстановку.

У роботі [7] приведено результати випробувань захисних властивостей штукатурки з наповнювачами $з$ феритного порошку та вуглецевих волокон у діапазоні мобільного зв'язку - 850-1880 МГц. Ці матеріали показали малі коефіцієнти відбиття, що найбільш важливо для такого частотного діапазону.

Аналогічне дослідження стосується вуглецевих фарб на основі графітизованої сажі [8]. Недоліком згаданих робіт є орієнтація виключно на високочастотні діапазони.

Щодо захисту від впливу електромагнітних полів конструкційними матеріалами, то найбільш грунтовними та достовірними $є$ роботи $з$ дослідження ефективності покрівельних матеріалів [9] та екрануючих властивостей будівельних матеріалів існуючих будівель [10]. У роботі [9] розглянуто захист від електромагнітних полів промислової частоти шифером, металочерепицею, листовою сталлю тощо. Отримані результати свідчать про їх достатню ефективність.

Наведені дані не стосуються магнітних полів, але у дослідженні [10] наведено, що будівлі із залізобетону мають коефіцієнти екранування магнітних полів промислової частоти 1,04-1,07, що явно недостатньо у сучасних умовах.

Наведений аналіз свідчить, що потребує розроблення й дослідження захисних властивостей матеріалів для захисту від впливу електромагнітних полів широкого частотного діапазону. Створення будівельних матеріалів 3 потрібними властивостями проблематичне через можливість зниження міцнісних характеристик за наявності в них екрануючих домішок.

Щодо облицювальних матеріалів, то їх механічні властивості менш критичні.

Запропоновані методики щодо визначення захисних властивостей електромагнітних екранів [11] та дослідження захисних властивостей різноманітних новітніх матеріалів [12] не правилом для всіх наступних експериментів. До того ж існує можливість регулювати захисті властивості облицювальних і оздоблювальних матеріалів, що неможливо для несучих конструкцій виробів.

\section{Виклад основного матеріалу}

Проведений аналіз відомостей щодо фактичних екрануючих властивостей будівельних матеріалів та розробок свідчить, що традиційні будівельні матеріали мають малі екрануючі властивості як у наднизькій області електромагнітного спектра та й ультрависокочастотній.

У таких умовах головною метою $є$ створення перспективних матеріалів для облицювання поверхонь будівель та приміщень. Для досягнення поставленої мети сформульовані наступні задачі:

- отримання матеріалів для облицювання зовнішніх та внутрішніх поверхонь великих площ, прийнятної вартості;
- максимально можлива уніфікація матеріалів та конструкцій, придатних для екранування;

3 економічної точки зору доцільно здійснювати облицювання екрануючими матеріалами внутрішньої поверхні. (Це знімає проблеми деградації матеріалів під впливом атмосферних чинників, герметичності нанесення на зовнішні поверхні тощо);

Для облицювання внутрішніх поверхонь стін ефективним $є$ застосування розробленого металополімерного матеріалу, який складався 3 поширеного та дешевого латексу та відходів збагачення залізної руди [13]. Екранувальні властивості цього матеріалу щодо електромагнітних випромінювань ультрависокої частоти наведено у табл. 1 .

\section{Таблиця 1 - Коефіціснти екранування та відбиття електромагнітних хвиль ультрависокої частоти в залежності від вмісту екрануючої субстанції у полімерній матриці товщинами 5 мм та 10 мм}

\begin{tabular}{|c|c|c|c|}
\hline \multirow{2}{*}{$\boldsymbol{\rho}, \boldsymbol{\%}$} & \multicolumn{2}{|c|}{$\boldsymbol{\kappa}_{\boldsymbol{e}}$} & \multirow{2}{*}{$\boldsymbol{K}_{\boldsymbol{~}}$} \\
\cline { 2 - 3 } & $\mathbf{5}$ мм & $\mathbf{1 0} \mathbf{~ м м}$ & \\
\hline 5 & 2 & 3 & 0,06 \\
\hline 10 & 10 & 19 & 0,10 \\
\hline 15 & 33 & 38 & 0,28 \\
\hline 20 & 44 & 52 & 0,32 \\
\hline
\end{tabular}

У табл. 1: $\rho$ - вміст металевої субстанції (за вагою); $K_{e}-$ загальний коефіцієнт екранування; $K_{6}-$ коефіцієнт відбиття, який не залежить від товщини матеріалу.

Коефіцієнт екранування магнітного поля промислової частоти наведено у табл. 2.

Табличя 2 - Залежність коефіціснтів екранування магнітного поля промислової частоти від вмісту екрануючої субстанції та товщини матеріалу

\begin{tabular}{|c|c|c|}
\hline \multirow{2}{*}{$\boldsymbol{\rho}, \boldsymbol{\%}$} & \multicolumn{2}{|c|}{$\boldsymbol{\kappa}_{\boldsymbol{e}}$} \\
\cline { 2 - 3 } & $\mathbf{5}$ мм & $\mathbf{1 0}$ мм \\
\hline 5 & 1,2 & 2,3 \\
\hline 10 & 4,6 & 10,8 \\
\hline 15 & 11,0 & 24,0 \\
\hline 20 & 15,0 & 38,0 \\
\hline
\end{tabular}

Наведені у табл. 1 та 2 дані свідчать, що коефіцієнти екранування електромагнітного поля ультрависокої частоти достатні навіть в умовах впливу радіотехнічних об'єктів великої потужності. При цьому коефіцієнти відбиття електромагнітних хвиль набагато нижчі, ніж у будь яких провідних матеріалів. Але щодо електромагнітних полів засобів мобільного зв'язку - вони можуть бути надлишковими, тобто повністю блокувати мобільний зв'язок (враховуючи прийнятні коефіцієнти екранування магнітного поля промислової частоти навіть у виробничих умовах експлуатації потужного електротехнічного обладнання).

Тому, під час планування запровадження екранування приміщень необхідно узгодити ступень екранування низькочастотного магнітного поля 3 потребами функціонування мобільного зв'язку. 
За відсутності необхідності отримання великих коефіцієнтів екранування в умовах облицювання поверхонь матеріалами типу гіпсокартону можливе запровадження екранування конструкціями, подібними до градієнтних екранів.

Відомо, що гіпсокартон кріпіться до стін спеціальними системами. Визначивши переважну частоту зовнішнього випромінювання, необхідно зробити зазор завтовшки $\lambda / 4$, де $\lambda$ - довжина падаючої хвилі. Згасання електромагнітної хвилі відбувається за відомим механізмом при взаємодії падаючої та відбитої хвилі. Єдиною умовою $є$ наявність на тильному боці гіпсокартонного листа металевої поверхні. У даному випадку тип металу не має значення. Головна умова - це провідність матеріалу.

На нашу думку, найбільш зручною поверхнею є поверхня провідної фарби, але на сьогоднішній день фарб, прийнятних за ціною для широкого застосування не виробляється. Зниження коефіцієнтів відбиття випромінювання обмежено значенням відносної діелектричної проникності підкладинки (для гіпсокартону $-3,0 \div 4,0$ ). У широкому діапазоні довжин хвиль коефіцієнт відбиття на нижче

$$
K_{b}=10 \lg \left(\frac{\sqrt{\varepsilon}-1}{\sqrt{\varepsilon}+1}\right)^{2} \text {, дБ, }
$$

який за цих умов складає $-8,0 \div 9,0$ дБ.

У облицювальній тришаровій структурі, де внутрішній шар - зазор між діелектриком і металевим покриттям завтовшки 0,5 максимальної довжини хвилі діапазону, коефіцієнт відбиття знизиться до $14,0 \div 17,0$ дБ у широкому діапазоні довжин хвиль. При цьому повинна виконуватись умова, що товщина зовнішньої оболонки $d$ та мінімальна довжина хвиль діапазону $\lambda_{\min }$ відповідає співвідношенню:

$$
\frac{d \sqrt{\varepsilon}}{\lambda_{\min }}<0,3 .
$$

За подальшого зменшення довжини хвилі коефіцієнт відбиття буде зростати й досягне максимального значення $-3,0 \div 4,0$ дБ за умови:

$$
\frac{d \sqrt{\varepsilon}}{\lambda_{\min }}=0,25 .
$$

Для одночасного екранування магнітного поля промислової частоти провідний шар повинен бути феромагнітним.

Враховуючи велику площу покриття, у якості такого шару можливо використовувати металополімер, подібний до описаного вище, але з більшим вмістом феромагнетика. У якості останнього доцільно використовувати концентрат залізної руди, який має відносну магнітну проникність 110-140.

Попередні вимірювання показали, що коефіцієнт екранування такого матеріалу, за вмісту феромагнетика $20 \%$ і товщини 1,0 мм, повинен складати $2,0-4,0$, що можна вважати задовільним. Недоліком цього матеріалу є низька технологічність при облицюванні поверхонь складної конфігурації та великий відсоток відходів.
Головною проблемою для проектування екрануючих конструкцій з використанням композитів $\epsilon$ те, що дані про магнітні та електрофізичні властивості металополімерів не $є$ табличними. Як правило, у довідковій літературі наведено відомості при властивості чистих металів або сплавів та полімерів широкого застосування. В принципі, маючі дані щодо показників металевої та металовмісної компоненти та полімеру (матриці) можливо розрахувати діелектричну проникність та провідність композиту. Співвідношення електродинаміки суцільних середовищ дозволяють розрахувати коефіцієнт заломлення матеріалу, а на його основі й діелектричної проникності - відносну магнітну проникність. Але в цьому випадку необхідно врахувати дійсну та уявну складові діелектричної проникності, що не завжди можливо та зручно. У результаті прогнозовані параметри матеріалу дуже приблизно і мало придатні для проектування матеріалів потрібних захисних властивостей. Крім того, за різної концентрації провідної субстанції параметри дуже відрізняються, а саме дрібно дисперсна субстанція, навіть за сприятливих умов розподілена у тілі полімеру не зовсім рівномірно. Для товщини 5-10 мм це некритично, відносно коефіцієнта екранування, але розрахунковий апарат це не враховує. Наприклад, відмінності у значеннях відносної діелектричної проникності за вмісту залізорудного пилу у полімерній матриці 10-15\% складають 5-85 і похибки досягають 20-25\%. Це ж стосується результатів провідності. Навіть дані щодо ефективної провідності серійної магнітної рідини 3 фіксованим вмістом феромагнітних наночастинок коливаються у межах 70-100, що незадовільно для розрахунків.

Найбільш раціональним на наш погляд, є отримання необхідних даних щодо магнітних та електрофізичних властивостях композиційних матеріалів 3 експериментів. Для ефективної магнітної проникності це можливо реалізувати за рахунок вимірювання коефіцієнта екранування магнітного поля. Існуючі співвідношення для коефіцієнтів екранування сферичними та циліндричними оболонками. Знаючи товщину стінки, радіуси оболонок та коефіцієнти екранування легко розраховуються ефективні магнітні проникності для композитів різного складу. Діелектричні проникності та питомі провідності визначаються прямими вимірюваннями. Це надає змогу отримати достатню кількість довідкових даних, але це потребує великих обсягів експериментальних робіт.

Тому, перспективним напрямком є розроблення металовмісної фарби з:

- прийнятними реологічними властивостями;

- доброю адгезією 3 найбільш поширеними металевими основами - поверхні, яка потребує покриття потрібною кількістю екрануючої фарби.

\section{Висновки}

1. На основі аналізу засобів екранування електромагнітних полів та випромінювань будівельними та облицювальними матеріалами показано, що найбільш ефективним зособом зниження впливу на 
працюючих зовнішніх полів, доцільне облицювання поверхонь будівель захисними матеріалами.

2. Розроблені металополімерні екрануючі матеріали гарантовано знижують електромагнітні поля ультрависокої частоти (2,4-2,6 ГГц) у 2,0-44,0 рази (за вмісту феромагнетику 5-20\%). Магнітне поле промислової частоти одночасно знижується у $1,2-15,0$ разів.

3. Наведено порядок однозначного визначення захисних властивостей конструкцій, виходячи 3 діелектричної проникності матеріалу основи та мінімальної довжини хвилі діапазону електромагнітних хвиль, що екрануються.

4. Показано, що для одночасного екранування високочастотних випромінювань та магнітного поля промислової частоти доцільно у якості провідного шару застосовувати металополімери з великим вмістом феромагнітної субстанції. Перспективним $\epsilon$ розроблення екрануючої фарби, яка може бути нанесена на основу у потрібній кількості.

\title{
СПИСОК ЛІТЕРАТУРИ
}

1. Панова О. В. Захист працюючих від впливу електромагнітних полів екрануванням: дис. ... канд. техн. наук: 05.26 .01$. Панова Олена Василівна. Київ, 2014. 151 с.

2. Панова О.В., Бірук Я.І. Концептуальні підходи до керування електромагнітною обстановкою у виробничих умовах / Міжнародна наукова інтернет-конференція "Інформаційне суспільство: технологічні, економічні та технічні аспекти становлення". Розділ Технічні науки. Секція «Безпека життєдіяльності». Випуск 47. С. 92-96. https://drive.google.com/file/d/1Bdbmn2miwiqf5gsv3a933sEgCwHJJfoW/view

3. Панова О.В. Загальні критерії застосування електромагнітних екранів для забезпечення електромагнітної безпеки та сумісності технічного обладнання. Наука та інновації. «Вісті Донецького гірничого інституту», Випуск 2, 2018. www.science.donntu.edu.ua

4. Проектування висотних житлових і громадських будинків ДБН В.2.2. - 24: 2009 - [Чинний від 01-10-09]. Київ. Мінрегіонбуд, 2009. 103 с. (Державні будівельні норми України).

5. Антипов С.А., Латыпов А.Ф., Пастернак Ю.Г. Обзор радиопоглощающих структур на основе электромагнитных искусственных поверхностей. Вестник Воронежского государственного технического университета. 2014. № 5-1. T. 10. С. $9-15$.

6. Мордачев В.И., Юрцев О.А., Литвинко П.А. Влияние декоративных металлических покрытий зданий на электромагнитную обстановку и электромагнитную совместимость радиосистем. Вестник белорусского государственного технического университета. 2009. № 6. С. $42-47$.

7. Беляев А.А., Беспалов А.А., Лепешкина В.В. Радиопоглощающие материалы на основе отделочных строительных материалов для защиты от СВЧ излучения базовых станций сотовых связи. Труды ВИАМ. 2015. № 6. С. 80-88.

8. Сеник І.В. Барсуков В.З., Крюкова В.А. Спеціальні покриття для захисту персоналу та спорядження від електромагнітного випромінювання. Легка промисловість. 2016. № 1. С. 18-24.

9. Графкіна М.В., Свиридова Е.Ю. Исследование эффективности электромагнитного экранирования кровельных строительных материалов. Вісник СГСУ. 2011. № 1. С. 413-416.

10. Пелевин Д.Е. Экранирование магнитного поля промышленной частоты стенами жилых домов. Електротехніка $\mathrm{i}$ електромеханіка. 2015. № 4. С. 53-55.

11. Панова О.В. Методика визначення захисних властивостей електромагнітних екранів. Техніка Будівництва: Науковотехнічний журнал Київ. 2010. Випуск 25. С. 74-76.

12. Глива. В.А., Панова О.В. Дослідження захисних властивостей матеріалів для екранування електромагнітних полів. III Міжнар. наук.-техн. конф. 7 квітня 2011 р. «Енергетика, Екологія, Людина». Київ. НТУУ «КПИ»

13. Glyva V., Lyashok J., Matvieieva I., Frolov V., Levchenko L., Tykhenko O., Panova O., Khodakovskyy O., Khalmuradov B., Nikolaiev K. Development and investigation of protective properties of the electromagnetic and soundproofing screen. Eastern-European Journal of Enterprise Technologies. 2018. Iss. 6/5 (96). P. 54-61. https://doi.org/10.15587/1729$\underline{4061.2018 .150778}$

Received (Надійшла) 12.03.2020

Accepted for publication (Прийнята до друку) 29.04.2020

\author{
Research of protective properties \\ of metal electromagnetic screens and determining \\ the conditions for their maximum efficiency
}

O. Panova

Abstract. Based on the analysis of data on the screening of electromagnetic fields of ultra-low and ultra-high frequencies of construction and cladding materials, it is concluded that the most appropriate for technical and economic reasons is lining the internal surfaces of buildings with protective materials. Shielding coefficients of the developed metal-polymer materials of electromagnetic fields of various frequencies are given below. For electromagnetic fields with frequencies of 2.4-2.6 GHz, the screening coefficients are 2.44 (with a screen thickness of $5 \mathrm{~mm}$ ) and 3-52 (with a screen thickness of $10 \mathrm{~mm}$ ). Reflection coefficients are $0.06-0.32$. The change in the concentration of ferromagnetic substance is $5-20 \%$ (by weight). Under such conditions, a decrease in the magnetic field of industrial frequency is 1.2-15.0 (with a screen thickness of $5 \mathrm{~mm}$ ) and 2.3-38.0 (with a screen thickness of $10 \mathrm{~mm}$ ). Proposed a procedure to be used for evaluating the effectiveness of shielding a high-frequency screened field with a three-layer structure, based on the value of the dielectric constant of the carrier material and the minimum electromagnetic wavelength range of the screened field. For simultaneous shielding of industrial frequency magnetic fields, the leading layer must be ferromagnetic. Metal polymers with a high concentration of iron ore concentrate can be used to achieve this.

Keywords : electromagnetic fields; shielding; screening factors; cladding protective building material. 